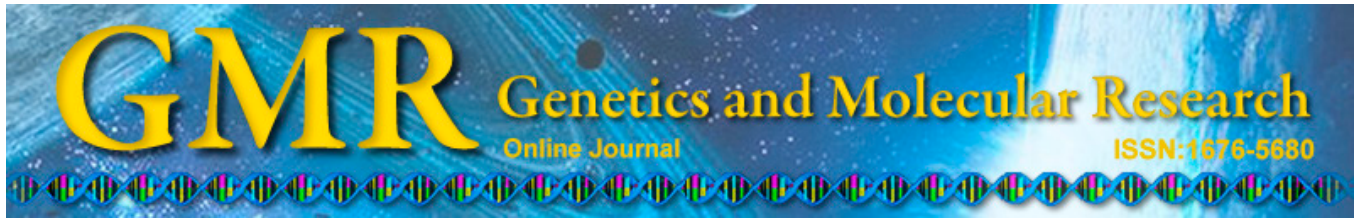

\title{
Expression of genes related to tolerance to low temperature for maize seed germination
}

\author{
I.C. Silva-Neta ${ }^{1}$, E.V. Pinho" ${ }^{1}$, A.D. Veiga ${ }^{2}$, R.G. Pìnho ${ }^{1}$, R.M. Guimarães ${ }^{1}$, \\ F. Caixeta ${ }^{1}$, H.O. Santos $^{1}$ and T.L. Marques ${ }^{1}$ \\ ${ }^{1}$ Departamento de Agricultura, Universidade Federal de Lavras, \\ Lavras, MG, Brasil \\ ${ }^{2}$ Embrapa Cerrados, CPAC, Planaltina, DF, Brasil \\ Corresponding author: I.C. Silva-Neta \\ E-mail: izabel_agronomia@hotmail.com
}

Genet. Mol. Res. 14 (1): 2674-2690 (2015)

Received May 27, 2014

Accepted October 20, 2014

Published March 30, 2015

DOI http://dx.doi.org/10.4238/2015.March.30.28

\begin{abstract}
The aim of this study was to characterize maize lines tolerant to cold temperatures during the germination process. Seeds from lines with different levels of tolerance to low temperatures were used; 3 lines were classified as tolerant and 3 as susceptible to low germination temperatures. A field was set up to multiply seeds from selected lines. After the seeds were harvested and classified, we conducted physiological tests and analyzed fatty acid content of palmitic, stearic, oleic, linoleic, linolenic, and eicosenoic acids. In proteomic analysis, the expression of heat-resistant proteins, including catalase, peroxidase, esterase, superoxide dismutase, and $\alpha$-amylase, were evaluated. Transcript analysis was used to measure the expression of the genes $A O X 1, A O X 2, Z m M P K-17$, and $Z m A N-13$. The material showing the highest susceptibility to low germination temperatures contained high saturated fatty acid content. Expression of $\alpha$-amylase in seeds soaked for $72 \mathrm{~h}$ at a temperature of $10^{\circ} \mathrm{C}$ was lower than expression of $\alpha$-amylase when soaked at $25^{\circ} \mathrm{C}$ for the same amount of time. We observed variation in the expression of heat-resistant proteins
\end{abstract}


in seeds of the lines evaluated. The genes $A O X$ and $Z m-A N 13$ were promising for use in identifying maize materials that are tolerant to low germination temperatures.

Key words: Abiotic stress; Fatty acids; Proteomics; Transcriptomics; Zea mays

\section{INTRODUCTION}

Maize is one of the most widely grown cereal crops worldwide, and genetic breeding programs have been used to develop breeds that are generally well adapted to diverse climatic conditions. However, when sown in soils that have temperatures lower than $10^{\circ} \mathrm{C}$, the germination process is negatively affected, which may seriously decrease production because of lack of uniformity and gaps in crop stand.

To increase corn production in low temperature regions, cultivars recommended for these locations should be tolerant to colder temperatures, particularly during the seed germination and seedling emergence stages. Thus, offering productive genotypes with tolerance to low temperatures is an important challenge for breeding programs.

However, factors affecting the response to cold are complex and the mechanisms of response to cold are not well-understood (Yang et al., 2011).

Thus, hybrids that are tolerant to low temperatures should be identified and characterized to determine genotypes related to this tolerance during the germination phase, as well as the mechanisms that confers this tolerance. Some authors have reported fatty acids (Uemura et al., 1995; Hughes and Dunn, 1996; Chinnusamy et al., 2007), increased antioxidant activity (Baek and Skinner, 2003; Farooq et al., 2008; Zhou et al., 2012), and the expression of specific genes as important defense mechanisms in the plant response to stress caused by low temperatures.

An increased understanding of these mechanisms during the germination process of maize seeds will facilitate the generation of new genetic materials, as well as contribute to the development of selection techniques that may reduce the time and work required for evaluating genetic sources of tolerance to low temperatures. Identification of these genes will not only increase the understanding of cold tolerance, but also will allow for the development of strategies to make plants more tolerant to low temperatures (Şahin-Çevik, 2013). The aim of this study was to characterize maize lines that are tolerant to cold temperatures during the germination process using physiological tests, fatty acid profile analysis, transcriptomics, and proteomics.

\section{MATERIAL AND METHODS}

The study was conducted in the experimental area and in the Central Seed Laboratory of the Department of Agriculture of the Universidade Federal de Lavras (UFLA) in Lavras, MG, Brazil. A field was set up for multiplication of seeds from 6 lines granted by the company Genes Seeds Ltda. in Lavras, MG, Brazil. Among the lines used, 3 were previously classified as tolerant to low germination temperature (lines 63, 64, and 91) and 3 were susceptible to low germination temperature (lines 44,54 , and 57 ).

To obtain the seeds, $810-\mathrm{m}$ rows were set up for each line, with a spacing of $0.8 \mathrm{~m}$ between rows and 5 plants per meter. Crop treatments were performed according to those recommended for the crop. 
At flowering, the plants were manually self-pollinated. The seeds were harvested when $100 \%$ of the endosperm was solid. After harvest, various aspects of the seeds were analyzed.

\section{Moisture content}

The moisture content of the seeds was determined by placing the seeds in a laboratory oven at $105^{\circ} \mathrm{C}$ for $24 \mathrm{~h}$, using 2 subsamples from each treatment, according to the Seed Analysis Guidelines (Regras para Análise de Sementes - RAS) (BRASIL, 2009). The results are reported as the mean percentage (wet base).

\section{Germination test and protrusion percentage at different temperatures}

For the germination tests, 4 temperatures were used $\left(10^{\circ}, 15^{\circ}, 20\right.$, and $\left.25^{\circ} \mathrm{C}\right)$. For each temperature, the test was conducted with 4 replications of 50 seeds, with seeding between Germitest-type paper moistened with distilled water at a proportion of 2.5 times the weight of the dry paper. The rolls were placed in plastic bags and kept in a biochemical oxygen demand chamber at temperatures of $10^{\circ}, 15^{\circ}, 20^{\circ}$, and $25^{\circ} \mathrm{C}\left( \pm 3^{\circ} \mathrm{C}\right)$. Normal seedlings were evaluated at $4,7,14$, and 21 days. The results are reported as the mean percentage of normal seedlings from the 4 replications. At least $1 \mathrm{~cm}$ of the main root and 2 adventitious roots, and $1 \mathrm{~cm}$ of the aboveground region was used for normal seedlings. The protrusion percentage was also evaluated, using seeds with at least $0.5 \mathrm{~cm}$ of protrusion as a standard.

\section{Germination speed and protrusion index}

Together with the germination test, the germination speed test was carried out through daily evaluations at the same time, calculating the number of seeds with root protrusions for up to 21 days after seeding. The data were analyzed using the formula described by Maguire (1962). At least $1 \mathrm{~cm}$ of the main root and 2 adventitious roots, and $1 \mathrm{~cm}$ of the aboveground region was used as the standard for normal seedlings. The protrusion speed index was also evaluated, using seeds with at least $0.5 \mathrm{~cm}$ of protrusion as a standard.

\section{Expression of heat-tolerant proteins}

For electrophoretic analysis of heat-resistant proteins, 11 whole dry seeds were used for each treatment. Seeds were ground for $1 \mathrm{~min}$ and $15 \mathrm{~s}$ in a mortar over ice in the presence of buffer solution (50 mM Tris-HCl, pH 7.5; $500 \mathrm{mM} \mathrm{NaCl} ; 5 \mathrm{mM} \mathrm{MgCl} ; 1 \mathrm{mM}$ phenylmethylsulfonyl fluoride) in a 1:10 proportion (weight of material:volume of extraction buffer), and transferred to $1.5-\mathrm{mL}$ microtubes. The homogenized materials were centrifuged at 14,000 rpm for $30 \mathrm{~min}$ at $4^{\circ} \mathrm{C}$ and the supernatant was incubated in a water bath at $85^{\circ} \mathrm{C}$ for $15 \mathrm{~min}$ and then centrifuged. The supernatant was poured into microtubes and the pellet was discarded. Before gel electrophoresis, samples containing $70 \mu \mathrm{L}$ extract and $40 \mu \mathrm{L}$ buffer solution from the sample $(2.5 \mathrm{~mL}$ glycerol; $0.46 \mathrm{~g}$ sodium dodecyl sulfate and $20 \mathrm{mg}$ bromophenol blue was added to $20 \mu \mathrm{L}$ extraction buffer (Tris, $\mathrm{pH} \mathrm{7.5)}$ ) and placed in a boiling water bath for $5 \mathrm{~min}$ (Blackman et al., 1991). Next, $50 \mu \mathrm{L}$ extract, containing proteins and buffer, was used for polyacrylamide gel electrophoresis (sodium dodecyl sulfate-PAGE) using a $12.5 \%$ separating gel and 6\% stacking gel. Electrophoresis was performed at $120 \mathrm{~V}$ and the gels were stained in 
Coomassie blue at $0.05 \%$ for $12 \mathrm{~h}$ and destained in $10 \%$ acetic acid solution (Alfenas, 2006a).

\section{$\alpha$-Amylase enzyme expression}

To extract $\alpha$-amylase enzyme, the seeds were germinated in a roll of paper for a period of $72 \mathrm{~h}$ at temperatures of $10^{\circ}$ and $25^{\circ} \mathrm{C}$. After this period, the embryonic axes and scutella of 11 seeds were discarded and the remaining endosperms were subjected to cold grinding in a cooled mill in the presence of liquid nitrogen. For extraction, $200 \mathrm{mg}$ powder from the seeds was resuspended in $600 \mu \mathrm{L}$ extraction buffer $(0.2 \mathrm{M}$ Tris- $\mathrm{HCl}, \mathrm{pH} 8.0+0.4 \%$ polyvinylpyrrolidone). Next, $40 \mu \mathrm{L}$ protein extract was applied to polyacrylamide gels with a $7.5 \%$ separating gel containing starch and 4.5\% stacking gel (Alfenas, 2006a).

\section{Expression of the enzymes catalase, esterase, peroxidase, and superoxide dismutase}

For electrophoretic analysis of the enzymes catalase, esterase, peroxidase, and superoxide dismutase, dry seeds soaked in rolls of paper for 24 and $48 \mathrm{~h}$ at temperatures of $10^{\circ}$ and $25^{\circ} \mathrm{C}$ were used. The seeds were ground in the presence of polyvinylpyrrolidone and liquid nitrogen in a cooled mill.

For enzyme extraction, buffer containing $0.2 \mathrm{M}$ Tris-HCl, $\mathrm{pH} 8.0$, and $0.1 \%$ $\beta$-mercaptoethanol was used at a proportion of $250 \mu \mathrm{L}$ per $100 \mathrm{mg}$ seeds. The material was homogenized in a vortex and stored overnight in a refrigerator, followed by centrifugation at $14,000 \mathrm{rpm}$ for $30 \mathrm{~min}$ at $4^{\circ} \mathrm{C}$.

Electrophoresis was carried out for $60 \mu \mathrm{L}$ supernatant in polyacrylamide gels with a $7.5 \%$ separating gel and $4.5 \%$ stacking gel at $120 \mathrm{~V}$ for $5 \mathrm{~h}$.

At the end of the run, the gels were processed according to the method described by Alfenas (2006b).

\section{Analysis of transcripts using quantitative reverse transcription (qRT)-polymerase chain reaction (PCR)}

Gene transcripts related to cold tolerance were examined using qRT-PCR, which was divided into 4 steps: RNA extraction and purification, reverse transcription to synthesize cDNA, real-time PCR, and analysis of results.

For RNA extraction, dry seeds from the 6 lines $(44,54,57,63,64$, and 91$)$ soaked for $48 \mathrm{~h}$ at $10^{\circ}$ and $25^{\circ} \mathrm{C}$ were used.

The maize seeds were macerated in liquid nitrogen and Pure Link RNA Plant ${ }^{\mathbb{B}}$ (Invitrogen, Carlsbad, CA, USA) following manufacturer instructions.

The integrity of the RNA was verified by $1 \%$ agarose gel electrophoresis and visualized after staining with ethidium bromide. Quantification of the RNA was carried out using a spectrophotometer at wavelengths of 260 and $280 \mathrm{~nm}$.

After extracting nucleic acids, the samples were treated with DNA-free DNase to removing contaminating DNA (Ambion, Austin, TX, USA) according to manufacturer recommendations. To demonstrate the effectiveness of decontamination, a conventional PCR was carried out for all samples. In this reaction, a DNA sample from maize seeds and the primers for the endogenous controls ubiquitin and alcohol dehydrogenase (ADH) were used as positive controls. Amplification products were evaluated on a 1.5\% agarose gel stained with ethidium bromide. 
After extraction and purification of RNA, cDNA synthesis was carried out. The High Capacity cDNA Reverse Transcription ${ }^{\circledR}$ kit from Applied Biosystems (Foster City, CA, USA) was used following the manufacturer protocol.

To analyze gene expression using qRT-PCR, the genes were selected based on literature review to identify important studies of plant tolerance to low temperatures. The primers used were designed using the Primer Express 3.0 software (Applied Biosystems), after searching for gene sequences (http://www.ncbi.nlm.nih.gov) (Table 1). The ubiquitin and $A D H$ genes were used as endogenous controls.

Table 1. Primer sequences used for qRT-PCR in seeds from different maize lines.

\begin{tabular}{|c|c|c|}
\hline Gene & Identification & Sequence (5'-3') \\
\hline$Z m A N-13^{*}$ & Unknown & $\begin{array}{l}\text { F: AGCTGTTGCCCAAGTCGAGTT } \\
\text { R: GCTGGGTCCGGCAACAT }\end{array}$ \\
\hline AOXI (precursor)* & Alternative route of respiration/antioxidant & $\begin{array}{l}\text { F: GCGAGGAGCAAACAGCAAA } \\
\text { R: GGCCACTAGTGCGGTCAACT }\end{array}$ \\
\hline AOX2 (precursor)* & Alternative route of respiration/antioxidant & $\begin{array}{l}\text { F: CCAAGACGCTGATGGATAAGG } \\
\text { R: AGCCATACCGCCTCTGGAA }\end{array}$ \\
\hline$Z m M P K-17^{*}$ & Mitogen-activated protein kinase & $\begin{array}{l}\text { F: CTCCGGTTGCTAGAGGGTTT } \\
\text { R: TGGATCAGCTAAAGCCTCTTCAG }\end{array}$ \\
\hline Ubiquitin* & Endogenous control & $\begin{array}{l}\text { F: AAGGCCAAGATCCAGGACAA } \\
\text { R: TTGCTTTCCAGCGAAGATGA }\end{array}$ \\
\hline Alcohol dehydrogenase $(A D H)^{*}$ & Endogenous control & $\begin{array}{l}\text { F: AGGACGCTGAGTTAAGACC } \\
\text { R: CACATTTGGCAGATCAGTGC }\end{array}$ \\
\hline
\end{tabular}

$\mathrm{F}=$ sequence of the forward primer; $\mathrm{R}=$ sequence of the reverse primer. *Amplification primers for seeds of the maize lines studied.

For analysis of quantitative gene expression by qRT-PCR, the equipment ABI PRISM 7500 Real-Time PCR (Applied Biosystems) and the detection system SYBR Green was used, and the cDNA was obtained from the RNA extracted from the seeds. The thermal conditions of the reaction were $2 \mathrm{~min}$ at $50^{\circ} \mathrm{C}, 10 \mathrm{~min}$ at $95^{\circ} \mathrm{C}$, followed by 40 cycles of $15 \mathrm{~s}$ at $95^{\circ} \mathrm{C}$ and $1 \mathrm{~min}$ at $60^{\circ} \mathrm{C}$, concluding with $15 \mathrm{~s}$ at $95^{\circ} \mathrm{C}$. The data were collected and stored in the 7500 software program (Version 2.0.1). For each reaction, $1.0 \mu \mathrm{L} \mathrm{cDNA}$ diluted 1:5, $0.2 \mu \mathrm{L}$ of each primer and 5.0 $\mu$ L Master Mix SYBR green with UDG and ROX (Invitrogen) were used for a final volume of $10.0 \mu \mathrm{L} / \mathrm{sample}$. Negative controls were included in the analyses and melting curves were evaluated.

Two biological replications were used in 3 technical replicates for each gene under study and the results were normalized using the threshold cycle $(\mathrm{Ct})$ obtained based on expression of the reference genes ubiquitin and $A D H$.

The $\mathrm{Ct}$ was determined as the number of cycles in which the fluorescence generated within a reaction crossed the threshold. The comparative $\mathrm{Ct}$ method was used. A validation experiment was first performed to verify that the efficiencies of amplification of the target genes and reference genes were similar and very close to $100 \%$ (Tyagi et al., 1998). Standard curves for the genes under study were generated from the following dilutions: 1:5, 1:25, 1:125, $1: 625$, and 1:3125. This procedure also allowed definition of the best dilution of cDNA in each reaction, which was 1:5.

Samples showing the lowest expression for each gene were used as calibration samples and relative expression was measured using the relative standard curve method as described in the apparatus manual (Applied Biosystems). To quantify gene expression using real-time PCR, the values obtained corresponding to sample mRNA levels were compared to 
the control mRNA level. Data were analyzed using the 7500 software SDS program (Version 2.0.1). To calculate gene expression levels, the following were considered: $\mathrm{Ct}$ (exponential increase in PCR product) of the target gene and endogenous control, $\Delta \mathrm{Ct}=\mathrm{Ct}$ (sample) - $\mathrm{Ct}$ (endogenous control) and $\Delta \Delta \mathrm{Ct}=\Delta \mathrm{Ct}$ (sample) - $\Delta \mathrm{Ct}$ (calibrator). Expression levels were then calculated using the formula: $\mathrm{RQ}=2^{-\Delta \Delta \mathrm{Ct}}$. The program Sigma Plot was used to plot the figures (Systat Software, Inc., San Jose, CA, USA).

\section{Analysis of fatty acids using gas chromatography (GC)}

For chromatographic analysis of the fatty acid profile, seeds from the 6 lines were soaked at $10^{\circ} \mathrm{C}$ for 24 and $48 \mathrm{~h}$; dry seeds were also used.

First, $0.5 \mathrm{~g}$ lyophilized sample was weighed on a precision balance $(0.1 \mathrm{mg})$ and macerated. Next, $1.0 \mathrm{~mL} \mathrm{H}_{2} \mathrm{O}, 3.0 \mathrm{~mL}$ methanol, and $1.6 \mathrm{~mL}$ chloroform were added and transferred to a $10-\mathrm{mL}$ tube and vortexed for $30 \mathrm{~s}$ to mix. The sample was centrifuged at $3500 \mathrm{rpm}$ for $15 \mathrm{~min}$ to form a 3-phase solution. The supernatant $\left(\mathrm{H}_{2} \mathrm{O}\right.$ and methanol) was discarded from this solution, breaking through the sample using a Pasteur pipette and pipetting part of the chloroform. The collected material was set aside and protected from light and heat for later filtering.

The material was filtered over filter paper appropriate for GC and dried with nitrogen air. To the lipid extract, we added $2 \mathrm{~mL} 0.5 \mathrm{M} \mathrm{NaOH}$ and methanol, the solution was placed in boiling water for $5 \mathrm{~min}$, and then cooled in ice water. A quantity of $2.5 \mathrm{~mL}$ esterification reagent $\left(10 \mathrm{~g}\right.$ ammonium chloride, $15 \mathrm{~mL} \mathrm{H}_{2} \mathrm{SO}_{4}$, and $300 \mathrm{~mL}$ methanol) was added to the solution and placed in boiling water for $5 \mathrm{~min}$, and then cooled in ice water. Next, $2 \mathrm{~mL}$ saturated $\mathrm{NaCl}$ solution was added and the mixture was vortexed for $10 \mathrm{~s} ; 2.5 \mathrm{~mL}$ hexane was added and votexed for $10 \mathrm{~s}$, followed by centrifugation at $3000 \mathrm{rpm}$ for $10 \mathrm{~min}$. The phases separated and the mixture of hexane and lipids was transferred to an amber bottle, dried with nitrogen air, and stored at $-80^{\circ} \mathrm{C}$ until analysis. Before analysis, the substrate was resuspended in $0.6 \mathrm{~mL}$ hexane.

Fatty acid composition was determined by chromatography in the gas phase, using the chromatograph GC-2010 (Shimadzu, Kyoto, Japan), equipped with mass detector and capillary column of cast silica with $30 \mathrm{~m}$ length and $0.25-\mathrm{mm}$ internal diameter, containing polyethylene glycol as the liquid stationary phase. The standard used was a mixture of 37 methyl esters (Supelco ${ }^{\mathrm{TM}}$ 37 Component FAME Mix, Bellefonte, PA, USA), from C:4 to C22:6, with 99.9\% purity.

The following operational parameters were used: split injection mode with 1:20 division ratio; injected volume of $1 \mu \mathrm{L}$; temperature of the detector of $240^{\circ} \mathrm{C}$; temperature of the injector of $220^{\circ} \mathrm{C}$; temperature programming: beginning at $60^{\circ} \mathrm{C}$ with linear ramp of $5^{\circ} \mathrm{C} / \mathrm{min}$ to $240^{\circ} \mathrm{C}$, remaining at this temperature for $5 \mathrm{~min}$, maintaining the heating ramp of $10^{\circ} \mathrm{C} / \mathrm{min}$ until reaching $270^{\circ} \mathrm{C}$, remaining at this temperature. For GC, the samples were redissolved in $0.5 \mathrm{~mL}$ hexane. Peaks were identified using the comparative method with the retention times of the fatty acid ester pattern, and peak areas were integrated and reported as percentage of area.

\section{Statistical analysis}

To analyze physiological quality testing results, joint analysis was conducted, regarding each temperature as different experiment. A completely randomized design with a $6 \mathrm{x}$ 4-factorial arrangement of 6 genotypes and 4 temperatures, with 4 replications, was used and 
mean values for the treatments were compared using the Scott-Knott test at the level of 5\% probability. Analyses were conducted using the statistical program SISVAR (Ferreira, 2004).

To analyze fatty acid profiling results, joint analysis was conducted for each association of soaking time and temperature in a completely randomized design with 4 replications. Comparison of the mean values of each treatment was conducted using the Scott-Knott test at the level of 5\% probability. Data were analyzed using SISVAR (Ferreira, 2004).

\section{RESULTS}

The mean moisture content of the seeds at the time of the tests was $12.8 \%$, with maximum variation of $1 \%$.

Analysis of variance (Table 2) revealed significant differences in interactions among the lines and the temperatures studied for all physiological characteristics evaluated.

Table 2. Summary of joint analysis for germination (GER), root protrusion (P), germination speed index (GSI), protrusion speed index (PSI), length of the above ground part (LAG), length of the root system (LRS), dry matter of the above ground part (DMAG), and dry matter of the root system (DMRS) of 6 maize lines subjected to 4 germination temperatures.

\begin{tabular}{lrcccccccc}
\hline & d.f. & GER (\%) & P (\%) & GSI & PSI & LAG $(\mathrm{cm})$ & LRS (cm) & DMAG (g) & DMRS (g) \\
\hline Temperature (T) & 3 & $2306.89^{*}$ & $356.82^{*}$ & $1876.94^{*}$ & $1587.77^{*}$ & $245.23^{*}$ & $287.64^{*}$ & $3.26^{*}$ & $0.78^{*}$ \\
Rep T & 12 & 10.22 & 2.18 & 0.22 & 0.36 & 0.38 & 0.91 & 0.01 & 0.00 \\
Line (L) & 5 & $490.27^{*}$ & $147.17^{*}$ & $8.14^{*}$ & $28.59^{*}$ & $33.32^{*}$ & $40.89^{*}$ & $0.20^{*}$ & $0.05^{*}$ \\
L x T & 15 & $245.55^{*}$ & $116.75^{*}$ & $3.12^{*}$ & $4.64^{*}$ & $8.60^{*}$ & $9.90^{*}$ & $0.09^{*}$ & $0.03^{*}$ \\
Error & 60 & 32.22 & 3.05 & 0.38 & 0.32 & 0.61 & 1.08 & 0.01 & 0.00 \\
CV (\%) & & 6.30 & 1.79 & 5.90 & 4.14 & 14.33 & 15.04 & 16.49 & 22.04 \\
Mean & & $90.08^{*}$ & 97.31 & 10.46 & 13.82 & 5.46 & 6.91 & 0.68 & 0.34 \\
\hline
\end{tabular}

d.f. $=$ degrees of freedom; Rep $\mathrm{T}=$ repetition $\mathrm{x}$ temperature; $\mathrm{CV}=$ coefficient of variation; Mean $=$ overall mean. *Significant at the level of $5 \%$ probability by the F-test.

Compared to the results of the germination test (Table 3), when the test was performed at $25^{\circ} \mathrm{C}$, there was no significant difference among the materials studied. However, as the temperature was reduced to $20^{\circ}, 15^{\circ}$, and $10^{\circ} \mathrm{C}$, stratification of the materials was observed regarding tolerance to low temperatures.

When the temperature was $20^{\circ} \mathrm{C}$, a reduction in the germination percentage of seeds from line 57 was observed, while the others did not differ significantly, maintaining germination percentage above $95 \%$.

Table 3. Germination percentage of 6 lines of maize subjected to different germination temperatures.

\begin{tabular}{lcccc}
\hline Lines & \multicolumn{3}{c}{ Temperatures } \\
\cline { 2 - 5 } & $10^{\circ} \mathrm{C}$ & $15^{\circ} \mathrm{C}$ & $20^{\circ} \mathrm{C}$ & $25^{\circ} \mathrm{C}$ \\
\hline 44 & $74.00^{\mathrm{Cb}}$ & $94.00^{\mathrm{Aa}}$ & $98.00^{\mathrm{Aa}}$ & $100.00^{\mathrm{Aa}}$ \\
54 & $47.00^{\mathrm{Dc}}$ & $82.00^{\mathrm{Bb}}$ & $96.00^{\mathrm{Aa}}$ & $99.00^{\mathrm{Aa}}$ \\
57 & $76.00^{\mathrm{Cc}}$ & $88.00^{\mathrm{Bb}}$ & $86.00^{\mathrm{Ab}}$ & $98.00^{\mathrm{Aa}}$ \\
63 & $83.00^{\mathrm{Bb}}$ & $98.00^{\mathrm{Aa}}$ & $94.00^{\mathrm{Aa}}$ & $99.00^{\mathrm{Aa}}$ \\
64 & $84.00^{\mathrm{Bb}}$ & $91.00^{\mathrm{Aa}}$ & $94.00^{\mathrm{Aa}}$ & $96.00^{\mathrm{Aa}}$ \\
91 & $93.00^{\mathrm{Aa}}$ & $99.00^{\mathrm{Aa}}$ & $97.00^{\mathrm{Aa}}$ & $100.00^{\mathrm{Aa}}$ \\
\hline
\end{tabular}

Results followed by the same uppercase letters in the column and lowercase letters in the row did not differ at $5 \%$ probability according to the Scott-Knott test. 
At $15^{\circ} \mathrm{C}$, seeds from lines 54 and 57 showed a lower germination percentage than the other lines. At $10^{\circ} \mathrm{C}$, the highest germination percentage was observed in seeds from line 91, followed by lines 63 and 64 . Germination less than $80 \%$ was observed for lines 57 and 44 and, in seeds from line 54 , this value was less than $50 \%$.

At all temperatures evaluated, line 91 showed a high germination percentage, and was greater than $90 \%$ when the test was performed at $10^{\circ} \mathrm{C}$.

According to the results of the protrusion percentage test (Table 4), at $25^{\circ}$ and $20^{\circ} \mathrm{C}$, there was no statistical difference among the lines. For $15^{\circ} \mathrm{C}$, lower values of protrusion were observed for lines 54 and 64 . The highest values of protrusion were observed at $10^{\circ} \mathrm{C}$ in seeds from lines 57 and 91.

The lowest protrusion percentage (Table 4) was observed in seeds from line 54, which was also observed in the germination test (Table 3 ).

Table 4. Protrusion percentage of 6 maize lines subjected to 4 germination temperatures.

\begin{tabular}{lcrrr}
\hline Lines & \multicolumn{3}{c}{ Temperatures } \\
\cline { 2 - 5 } & $10^{\circ} \mathrm{C}$ & $15^{\circ} \mathrm{C}$ & $20^{\circ} \mathrm{C}$ & \\
\hline 44 & $96.50^{\mathrm{Ab}}$ & $100.00^{\mathrm{Aa}}$ & $100.00^{\mathrm{Aa}}$ & $100.00^{\mathrm{Aa}}$ \\
54 & $69.50^{\mathrm{Cc}}$ & $96.00^{\mathrm{Bb}}$ & $100.00^{\mathrm{Aa}}$ & $100.00^{\mathrm{Aa}}$ \\
57 & $97.50^{\mathrm{Aa}}$ & $100.00^{\mathrm{Aa}}$ & $99.00^{\mathrm{Aa}}$ & $99.00^{\mathrm{Aa}}$ \\
63 & $94.00^{\mathrm{Bb}}$ & $99.00^{\mathrm{Aa}}$ & $100.00^{\mathrm{Aa}}$ & $100.00^{\mathrm{Aa}}$ \\
64 & $94.00^{\mathrm{Bb}}$ & $96.00^{\mathrm{Bb}}$ & $99.50^{\mathrm{Aa}}$ & $98.50^{\mathrm{Aa}}$ \\
91 & $98.00^{\mathrm{Aa}}$ & $100.00^{\mathrm{Aa}}$ & $100.00^{\mathrm{Aa}}$ & $100.00^{\mathrm{Aa}}$ \\
\hline
\end{tabular}

Results followed by the same uppercase letters in the column and lowercase letters in the row did not differ at $5 \%$ probability according to the Scott-Knott test.

The results from the protrusion speed index (PSI) (Table 5) showed that at temperatures of $25^{\circ}$ and $20^{\circ} \mathrm{C}$, lines 44 and 91 were higher than the others. When the temperature was $15^{\circ} \mathrm{C}$, line 44 was higher than the others.

Table 5. Protrusion speed index of 6 maize lines subjected to 4 germination temperatures.

\begin{tabular}{llrrr}
\hline Lines & \multicolumn{3}{c}{ Temperatures } \\
\cline { 2 - 5 } & $10^{\circ} \mathrm{C}$ & $15^{\circ} \mathrm{C}$ & $20^{\circ} \mathrm{C}$ & $25^{\circ} \mathrm{C}$ \\
\hline 44 & $5.57^{\mathrm{Ad}}$ & $13.57^{\mathrm{Ac}}$ & $20.50^{\mathrm{Ab}}$ & $24.00^{\mathrm{Aa}}$ \\
54 & $2.9^{\mathrm{Bd}}$ & $8.13^{\mathrm{Dc}}$ & $17.25^{\mathrm{Bb}}$ & $23.50^{\mathrm{Ba}}$ \\
57 & $5.04^{\mathrm{Ad}}$ & $9.04^{\mathrm{Cc}}$ & $16.75^{\mathrm{Bb}}$ & $21.25^{\mathrm{Ca}}$ \\
63 & $4.5^{\mathrm{Ad}}$ & $8.33^{\mathrm{Dc}}$ & $16.50^{\mathrm{Bb}}$ & $20.75^{\mathrm{Ca}}$ \\
64 & $5.13^{\mathrm{Ad}}$ & $9.00^{\mathrm{Cc}}$ & $17.00^{\mathrm{Bb}}$ & $23.00^{\mathrm{Ba}}$ \\
91 & $5.35^{\mathrm{Ad}}$ & $9.93^{\mathrm{Bc}}$ & $20.25^{\mathrm{Ab}}$ & $24.50^{\mathrm{Aa}}$ \\
\hline
\end{tabular}

Results followed by the same uppercase letters in the column and lowercase letters in the row did not differ at $5 \%$ probability according to the Scott-Knott test.

At $10^{\circ} \mathrm{C}$, a lower PSI (Table 6) was observed in seeds from line 54, which was similar to that observed for protrusion percentage (Table 5). Seeds from line 54 that did not protrude remained alive.

The results of the germination speed index (Table 6) were similar to those of the PSI. At $10^{\circ} \mathrm{C}$, line 54 showed lower values than the others. At $15^{\circ} \mathrm{C}$, lines 54 and 57 were lower, and at $20^{\circ}$ and $25^{\circ} \mathrm{C}$, lines 91 and 44 were higher than the other lines.

Examination of the fatty acid profile of dry seeds (Table 7) showed that lines 44 and 
54 contained the highest percentage of palmitic acid, which is a saturated fatty acid. These 2 lines were classified as having low cold tolerance during germination. Lines 44 and 57 contained the lowest content of unsaturated oleic fatty acid.

Table 6. Germination rate index of 6 maize lines subjected to 4 germination temperatures.

\begin{tabular}{lcccc}
\hline Lines & \multicolumn{3}{c}{ Temperatures } \\
\cline { 2 - 5 } & $10^{\circ} \mathrm{C}$ & $15^{\circ} \mathrm{C}$ & $20^{\circ} \mathrm{C}$ & $25^{\circ} \mathrm{C}$ \\
\hline 44 & $2.75^{\mathrm{Ad}}$ & $6.00^{\mathrm{Ac}}$ & $11.25^{\mathrm{Ab}}$ & $24.00^{\mathrm{Aa}}$ \\
54 & $1.25^{\mathrm{Bd}}$ & $4.75^{\mathrm{Bc}}$ & $10.50^{\mathrm{Bb}}$ & $23.50^{\mathrm{Ba}}$ \\
57 & $3.00^{\mathrm{Ad}}$ & $5.00^{\mathrm{Bc}}$ & $8.75^{\mathrm{Cb}}$ & $21.25^{\mathrm{Ca}}$ \\
63 & $3.50^{\mathrm{Ad}}$ & $5.75^{\mathrm{Ac}}$ & $10.50^{\mathrm{Bb}}$ & $20.75^{\mathrm{Ca}}$ \\
64 & $3.50^{\mathrm{Ad}}$ & $5.50^{\mathrm{Ac}}$ & $10.75^{\mathrm{Bb}}$ & $23.00^{\mathrm{Ba}}$ \\
91 & $3.50^{\mathrm{Ad}}$ & $6.00^{\mathrm{Ac}}$ & $11.75^{\mathrm{Ab}}$ & $24.50^{\mathrm{Aa}}$ \\
\hline
\end{tabular}

Results followed by the same uppercase letters in the column and lowercase letters in the row did not differ at $5 \%$ probability according to the Scott-Knott test.

Table 7. Profile of 6 fatty acids in dry seeds of 6 maize lines.

\begin{tabular}{|c|c|c|c|c|c|c|}
\hline \multirow[t]{2}{*}{ Lines } & \multicolumn{6}{|c|}{ Dry seeds } \\
\hline & Palmitic acid & Stearic acid & Eicosenoic acid & Oleic acid & Linoleic acid & Linolenic acid \\
\hline 44 & $15.45^{\mathrm{A}}$ & $2.70^{\mathrm{A}}$ & $0.16^{\mathrm{A}}$ & $21.19^{\mathrm{F}}$ & $58.70^{\mathrm{A}}$ & $1.02^{\mathrm{A}}$ \\
\hline 54 & $15.86^{\mathrm{A}}$ & $1.62^{\mathrm{A}}$ & $0.28^{\mathrm{A}}$ & $32.84^{\mathrm{B}}$ & $46.96^{\mathrm{B}}$ & $1.10^{\mathrm{A}}$ \\
\hline 57 & $9.37^{\mathrm{C}}$ & $1.36^{\mathrm{A}}$ & $0.06^{\mathrm{A}}$ & $22.47^{\mathrm{E}}$ & $61.46^{\mathrm{A}}$ & $1.34^{\mathrm{A}}$ \\
\hline 63 & $12.04^{\mathrm{B}}$ & $1.99^{\mathrm{A}}$ & $0.24^{\mathrm{A}}$ & $34.16^{\mathrm{A}}$ & $49.39^{\mathrm{B}}$ & $0.99^{\mathrm{A}}$ \\
\hline 64 & $10.84^{\mathrm{B}}$ & $1.49^{\mathrm{A}}$ & $0.09^{\mathrm{A}}$ & $24.09^{\mathrm{D}}$ & $60.97^{\mathrm{A}}$ & $1.20^{\mathrm{A}}$ \\
\hline 91 & $11.71^{\mathrm{B}}$ & $2.14^{\mathrm{A}}$ & $0.19^{\mathrm{A}}$ & $26.57^{\mathrm{C}}$ & $57.34^{\mathrm{A}}$ & $1.20^{\mathrm{A}}$ \\
\hline CV (\%) & 3.82 & 9.95 & 37.24 & 1.54 & 2.39 & 20.38 \\
\hline
\end{tabular}

Results followed by the same letter did not differ among themselves at $5 \%$ probability by the Scott-Knott test.

When the seeds were soaked for $24 \mathrm{~h}$ at $10^{\circ} \mathrm{C}$ (Table 8), lines 54 and 63 contained lower percentages of linoleic acid; however, line 63 , in contrast with line 54 , contained a higher percentage of oleic acid, which is also an unsaturated chain fatty acid. For the other fatty acids evaluated, there were no significant differences among the lines when soaked at $10^{\circ} \mathrm{C}$ for $24 \mathrm{~h}$.

Table 8. Profile of 6 fatty acids in seeds from 6 maize lines soaked for $24 \mathrm{~h}$ at $10^{\circ} \mathrm{C}$.

\begin{tabular}{|c|c|c|c|c|c|c|}
\hline \multirow[t]{2}{*}{ Lines } & \multicolumn{6}{|c|}{ Seeds soaked for $24 \mathrm{~h}$ at $10^{\circ} \mathrm{C}$} \\
\hline & Palmitic acid & Stearic acid & Eicosenoic acid & Oleic acid & Linoleic acid & Linolenic acid \\
\hline 44 & $12.82^{\mathrm{A}}$ & $2.20^{\mathrm{A}}$ & $0.16^{\mathrm{A}}$ & $21.67^{\mathrm{E}}$ & $60.23^{\mathrm{A}}$ & $1.28^{\mathrm{A}}$ \\
\hline 54 & $16.15^{\mathrm{A}}$ & $1.59^{\mathrm{A}}$ & $0.27^{\mathrm{A}}$ & $32.39^{\mathrm{B}}$ & $47.38^{\mathrm{B}}$ & $1.08^{\mathrm{A}}$ \\
\hline 57 & $12.66^{\mathrm{A}}$ & $2.06^{\mathrm{A}}$ & $0.16^{\mathrm{A}}$ & $20.53^{\mathrm{E}}$ & $62.57^{\mathrm{A}}$ & $1.25^{\mathrm{A}}$ \\
\hline 63 & $11.89^{\mathrm{A}}$ & $1.74^{\mathrm{A}}$ & $0.21^{\mathrm{A}}$ & $34.15^{\mathrm{A}}$ & $50.16^{\mathrm{B}}$ & $0.75^{\mathrm{A}}$ \\
\hline 64 & $11.18^{\mathrm{A}}$ & $1.65^{\mathrm{A}}$ & $0.19^{\mathrm{A}}$ & $23.54^{\mathrm{D}}$ & $60.26^{\mathrm{A}}$ & $1.30^{\mathrm{A}}$ \\
\hline 91 & $12.07^{\mathrm{A}}$ & $2.04^{\mathrm{A}}$ & $0.19^{\mathrm{A}}$ & $26.28^{\mathrm{C}}$ & $57.06^{\mathrm{A}}$ & $1.40^{\mathrm{A}}$ \\
\hline CV $(\%)$ & 17.09 & 23.61 & 12.18 & 2.45 & 4.52 & 27.05 \\
\hline
\end{tabular}

Results followed by the same letter did not differ at $5 \%$ probability according to the Scott-Knott test.

Based on the fatty acid profiles when the seeds were soaked for $48 \mathrm{~h}$ at $10^{\circ} \mathrm{C}$ (Table 9), a higher percentage of the saturated stearic fatty acid and lower percentage of the unsaturated oleic fatty acid in seeds from line 44 were observed. Seeds from lines 54 and 63 contained a higher percentage of oleic acid. However, in seeds from line 54, there was a lower percent- 
age of linoleic acid. Under these conditions, there was no significant difference among seeds regarding eicosenoic and linolenic acid contents.

Table 9. Profile of 6 fatty acids in seeds from six maize lines soaked for $48 \mathrm{~h}$ at $10^{\circ} \mathrm{C}$.
\begin{tabular}{lcccccc}
\hline Lines & \multicolumn{7}{c}{ Seeds soaked for $48 \mathrm{~h}$ at $10^{\circ} \mathrm{C}$} \\
& Palmitic acid & Stearic acid & Eicosenoic acid & Oleic acid & Linoleic acid & Linolenic acid \\
\hline 44 & $15.61^{\mathrm{B}}$ & $2.59^{\mathrm{A}}$ & $0.14^{\mathrm{A}}$ & $20.91^{\mathrm{D}}$ & $59.14^{\mathrm{A}}$ & $0.89^{\mathrm{A}}$ \\
54 & $16.33^{\mathrm{A}}$ & $1.60^{\mathrm{C}}$ & $0.25^{\mathrm{A}}$ & $32.95^{\mathrm{A}}$ & $46.50^{\mathrm{D}}$ & $1.07^{\mathrm{A}}$ \\
57 & $10.41^{\mathrm{E}}$ & $1.73^{\mathrm{C}}$ & $0.17^{\mathrm{A}}$ & $24.20^{\mathrm{C}}$ & $61.19^{\mathrm{A}}$ & $1.44^{\mathrm{A}}$ \\
63 & $12.17^{\mathrm{C}}$ & $1.68^{\mathrm{C}}$ & $0.20^{\mathrm{A}}$ & $33.78^{\mathrm{A}}$ & $50.51^{\mathrm{C}}$ & $0.74^{\mathrm{A}}$ \\
64 & $10.94^{\mathrm{D}}$ & $1.43^{\mathrm{C}}$ & $0.16^{\mathrm{A}}$ & $25.20^{\mathrm{C}}$ & $60.59^{\mathrm{A}}$ & $1.04^{\mathrm{A}}$ \\
91 & $11.94^{\mathrm{C}}$ & $2.15^{\mathrm{B}}$ & $0.19^{\mathrm{A}}$ & $27.00^{\mathrm{B}}$ & $56.53^{\mathrm{B}}$ & $1.20^{\mathrm{A}}$ \\
$\mathrm{CV}(\%)$ & 1.35 & 5.58 & 11.05 & 2.99 & 1.24 & 11.28 \\
\hline
\end{tabular}

Results followed by the same letter did not differ at $5 \%$ probability according to the Scott-Knott test.

Expression of the enzymes catalase (Figure 1A and B), peroxidase (Figure 1C and $\mathrm{D}$ ), esterase (Figure 1E and F), and superoxide dismutase (Figure $1 \mathrm{G}$ and $\mathrm{H}$ ) increased when soaking time was increased from 24 to $48 \mathrm{~h}$ at $25^{\circ} \mathrm{C}$. This was not observed for seeds soaked at $10^{\circ} \mathrm{C}$.

Regardless of the soaking time and temperature, the highest catalase expression was observed in line 63 (Figure 1A and B). Soaking of the seeds for $24 \mathrm{~h}$ at $10^{\circ} \mathrm{C}$ (Figure 1A) did not increase catalase expression compared to that observed in dry seeds. In lines 44 and 57, reduced catalase expression compared to dry seeds was observed for seeds soaked for $24 \mathrm{~h}$ at $10^{\circ} \mathrm{C}$. However, when the seeds were soaked for $48 \mathrm{~h}$, greater catalase activity was observed at $25^{\circ} \mathrm{C}$ for all lines (Figure 1B).

Peroxidase expression was observed in dry seeds from lines 44 and 63 . When the seeds were soaked at $10^{\circ}$ and $25^{\circ} \mathrm{C}$ for $24 \mathrm{~h}$, the pattern of expression was very similar to that observed in dry seeds in these lines. For other lines, there was no peroxidase expression in dry seeds and seeds soaked at $10^{\circ}$ and $25^{\circ} \mathrm{C}$ for $24 \mathrm{~h}$ (Figure 1C).

When the seeds were soaked for $48 \mathrm{~h}$ at $25^{\circ} \mathrm{C}$, new isoforms of peroxidase were observed in all lines, with an increase in expression compared to that observed in dry seeds and seeds soaked at $10^{\circ} \mathrm{C}$. In seeds soaked for $48 \mathrm{~h}$ at $10^{\circ} \mathrm{C}$, the expression pattern of peroxidase was similar to that observed in dry seeds (Figure 1D).

In the lines studied, esterase activity was observed in dry seeds (Figure 1E). When the seeds were soaked for $24 \mathrm{~h}$ at $10^{\circ}$ and $25^{\circ} \mathrm{C}$, there was no significant difference in the expression pattern of this enzyme compared to dry seeds, except for line 44 , which showed reduced expression when the seeds were soaked for $24 \mathrm{~h}$ at $10^{\circ}$ and $25^{\circ} \mathrm{C}$ (Figure $1 \mathrm{E})$. When the seeds were soaked for $48 \mathrm{~h}$ at $25^{\circ} \mathrm{C}$, new isoforms were observed, indicating increased enzymatic activity. For seeds soaked at $10^{\circ} \mathrm{C}$ for $48 \mathrm{~h}$, esterase expression was similar to that in dry seeds (Figure 1F). Regardless of the period of soaking and of temperature, greater esterase expression was observed in seeds from lines 57 and 64 and lower expression in seeds from line 91.

For most of the lines, expression of superoxide dismutase was higher in seeds soaked for $48 \mathrm{~h}$ at $25^{\circ} \mathrm{C}$ (Figure $1 \mathrm{H}$ ) than others treatments.

Analysis of expression of $\alpha$-amylase in maize seeds soaked at 10 and at $25^{\circ} \mathrm{C}$ for 72 $\mathrm{h}$ revealed that low temperature inhibits the activity of this enzyme (Figure 1I). When maize seeds were soaked for $72 \mathrm{~h}$ at $25^{\circ} \mathrm{C}, \alpha$-amylase was expressed in seeds from all lines, and 
lower expression was observed in seeds from line 91 . For seeds soaked at $10^{\circ} \mathrm{C}$ for $72 \mathrm{~h}$, $\alpha$-amylase expression was lower.

Figure $1 \mathrm{~J}$ shows the zymogram of expression of heat-resistant proteins. Similar patterns were observed in seeds of lines 63 and 91. In seeds from line 44, lower expression of heat-resistant proteins was observed, indicating this line's low tolerance to low germination temperature.

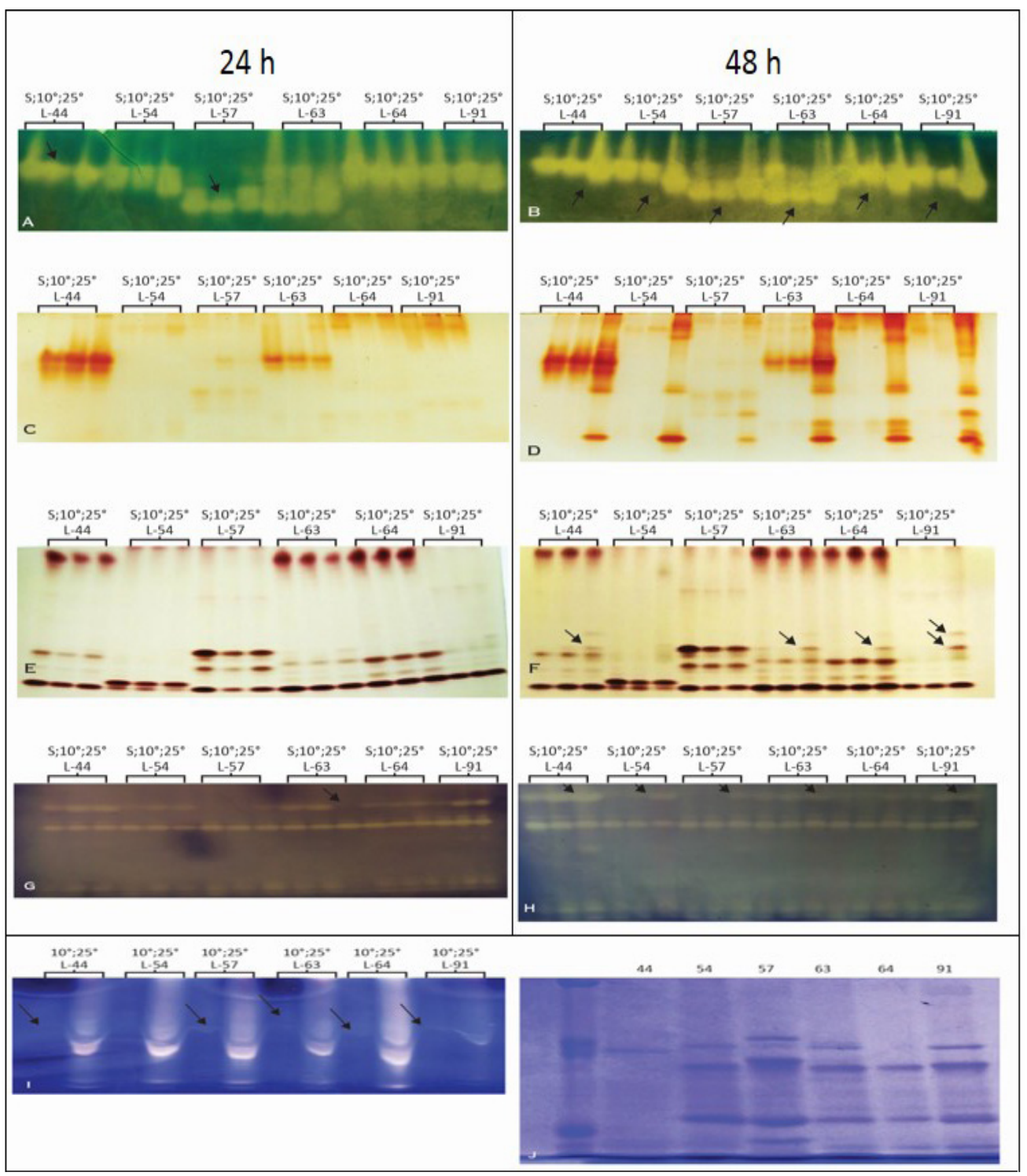

Figure 1. Expressions of protein standards. Catalase (A, B); peroxidase $(\mathbf{C}, \mathbf{D})$; esterase $(\mathbf{E}, \mathbf{F})$; superoxide dismutase $(\mathbf{G}, \mathbf{H})$; and $\alpha$-amylase $(\mathbf{I})$ and high temperature-tolerant proteins $(\mathbf{J})$ in S: dry seeds; $10^{\circ} \mathrm{C}$ : seeds imbibed at $10^{\circ} \mathrm{C}$; $25^{\circ} \mathrm{C}$ : seeds soaked at $25^{\circ} \mathrm{C}$, for 24 and $48 \mathrm{~h}$. 
Figure 2 shows the relative expression of the alternative oxidase 1 gene $(A O X 1)$ compared to seeds from line 63 soaked at $10^{\circ} \mathrm{C}$. This gene was only expressed in dry seeds from lines 63, 64, and 91, with greater expression in seeds from line 64. When the seeds were soaked at $25^{\circ} \mathrm{C}, \mathrm{AOX} 1$ expression was only observed in line 64 . Following soaking at $10^{\circ} \mathrm{C}$, which is the stress condition, expression was only observed in seeds from lines 63, 64, and 91, with greater expression in line 64, followed by lines 91 and 63 .

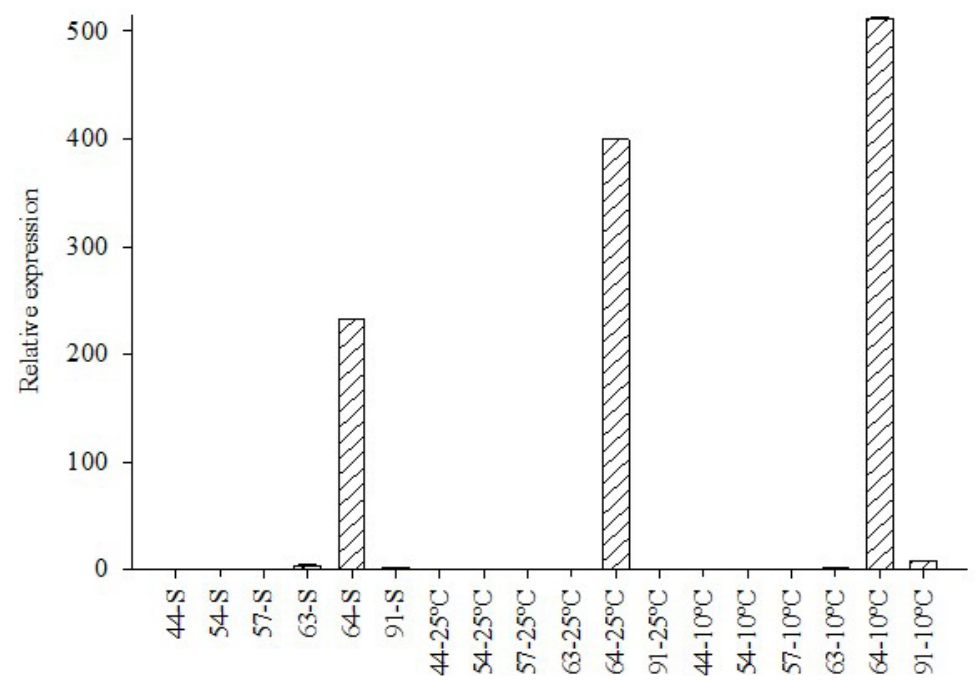

Figure 2. $A O X 1$ gene expression following treatment in line 63 at $10^{\circ} \mathrm{C}$.

Figure 3 shows the relative expression of the gene ZmMPK-17 compared to seeds from line 64-S. When the seeds were soaked at $25^{\circ} \mathrm{C}$, greater expression was observed in line 64 , followed by $63,54,91,44$, and 57 . At $10^{\circ} \mathrm{C}, \mathrm{ZmMPK}-17$ expression was similar in all lines.

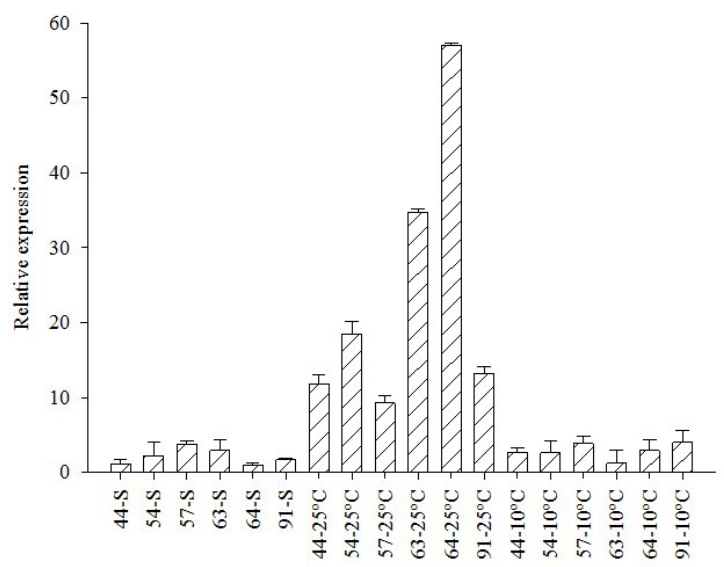

Figure 3. $\mathrm{ZmMPK}-17$ gene expression following treatment in line $64-\mathrm{S}$ at $10^{\circ} \mathrm{C}$. 
Figure 4 shows the relative expression of the gene $Z m A N-13$ compared to the sample of line 64 at $25^{\circ} \mathrm{C}$. In dry seeds, higher gene expression was observed in seeds from line 91, followed by lines 57 and 44 . When the seeds were soaked at $25^{\circ} \mathrm{C}, \mathrm{ZmAN}-13$ expression was low in all lines, but when the seeds were soaked at $10^{\circ} \mathrm{C}$, it was possible to separate the tolerant materials from the susceptible materials. This is because gene expression was higher in materials 63, 64, and 91 .

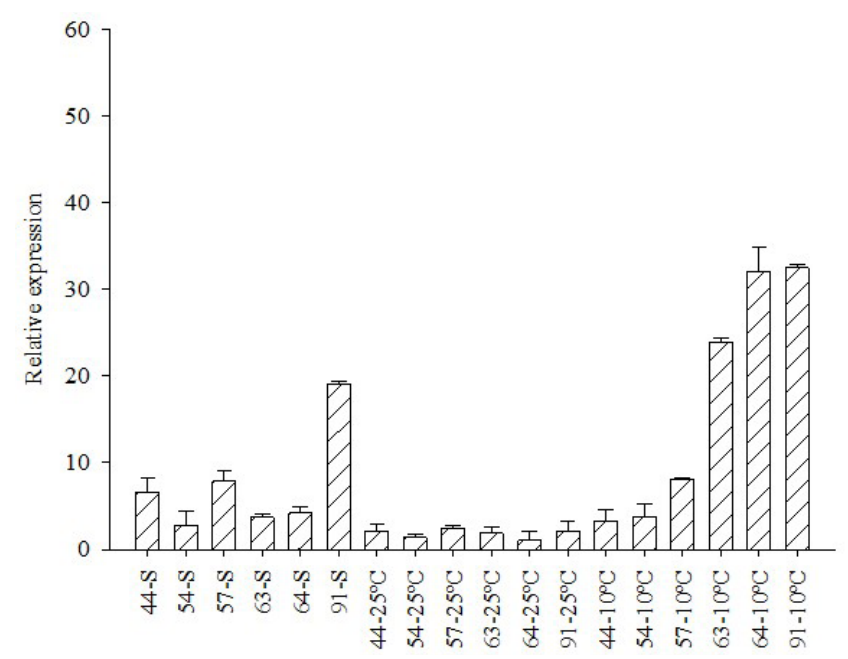

Figure 4. $Z m A N-13$ gene expression following treatment in line 64 at $25^{\circ} \mathrm{C}$.

Figure 5 shows the relative expression of gene $A O X 2$ compared to sample of line 54 at $10^{\circ} \mathrm{C}$. At $10^{\circ} \mathrm{C}$, the lowest expression of this gene was in seeds from line 54 and the highest expression of this gene was observed in line 63, followed by 44 and 91 .

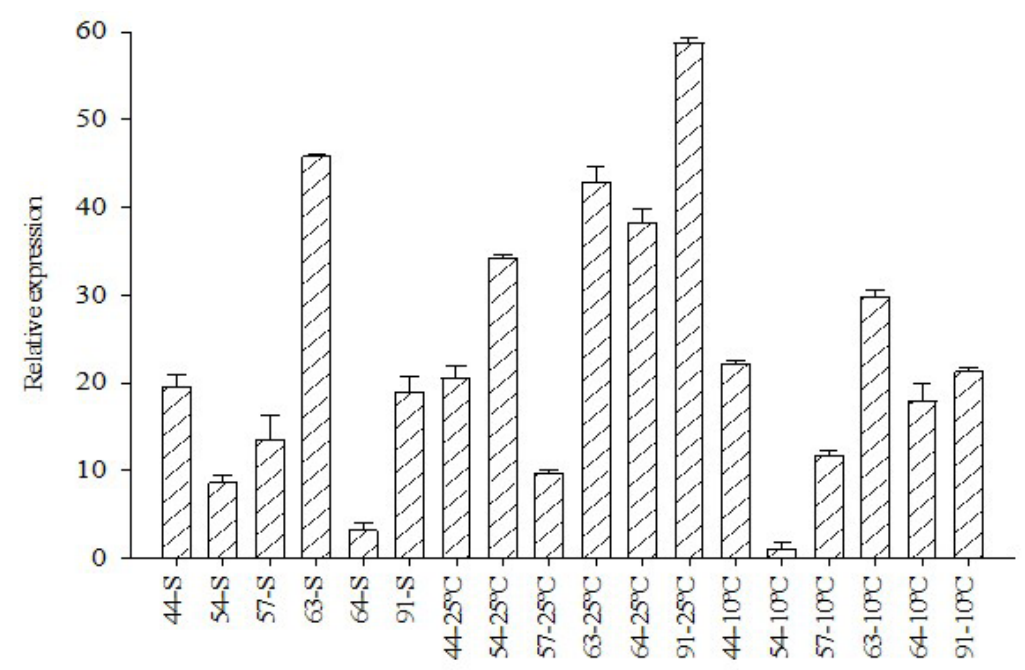

Figure 5. $A O X 2$ gene expression following treatment in line 54 at $10^{\circ} \mathrm{C}$. 


\section{RESULTS AND DISCUSSION}

For the physiological tests, in general, as the temperature decreased, stratification of the lots regarding tolerance to low temperature occurred because greater values of germination were observed in seeds from lines that were more tolerant to cold, indicating the effect of the genotype on this characteristic. Li et al. (2013), examining the induction of cold tolerance in wheat seeds during germination, observed that when the seeds were germinated at $12^{\circ} \mathrm{C}$, the germination rate was much lower than the germination rate of the same materials at $22^{\circ} \mathrm{C}$.

Line 91 showed high tolerance to low temperatures, making this material promising for studies of tolerance to low temperatures during germination.

According to Ullmannová et al. (2013), the 3 key characteristics of seed vigor in Brassica oleracea were rapid germination, rapid growth of the root system, and high growth potential of the above ground part of the plant, with an increase in resistance to cold. These characteristics imply a strategy for stress evasion. Thus, in addition to percentage and speed of protrusion, it is important to evaluate the germination percentage. For the success of this crop, the seed must germinate and give rise to normal seedlings. Line 44 showed a high percentage of protrusion but could not produce normal seedlings at the same rate; thus, it was not considered to be tolerant to low germination temperatures.

Rate of germination is also an important characteristic to evaluate in programs when selecting materials with tolerance to low germination temperatures. Line 54, in addition to its low germination percentage, showed a low germination rate, and thus this material was considered to be susceptible to the stress condition caused by low temperatures. Protruded seeds below the soil surface may favor attack from pests and diseases and may be less competitive to weed infestation. The use of low-vigor seeds is associated with increased weed plant biomass from 169 to $210 \%$ and reduced crop yield from 16 to $21 \%$ (Rasmussen, 2000).

In this study, evaluation of physiological quality allowed classification of the lines to determine cold tolerance during seed germination, with lines 44, 54, and 57 classified as having low cold tolerance and lines 63,64 , and 91 classified as tolerant to cold conditions.

The results obtained in this study show that temperature affects seedling development, but often the line that showed the greatest germination did not show the greatest growth rates. Cold tolerance is a very complex characteristic, and evaluation of morphological traits alone is not sufficient for ensuring selection of tolerant materials. This explains the need for association of these results with those observed from biochemical, proteomic, and transcriptomic analyses.

The plant's capacity to overcome stress caused by low temperatures is not constant, but increases considerably after progressive exposure to low temperatures. Higher lipid levels in the membrane increase the chance of retaining membrane fluidity and continuing activities, even at low temperatures. The higher percentage of saturation of fatty acids in lines 44 and 54 may have caused these lines to be more susceptible to low temperatures.

In an examination of cold tolerance in chickpea plants, Shahandashti et al. (2013) observed that during acclimation to cold, unsaturated fatty acid content increased compared to saturated fatty acid content. This increase in the unsaturated fatty acid content resulted from desaturase activity. These authors observed that when the plants were subjected to low temperatures, linolenic acid content increased considerably.

Plant tolerance to the stress caused by low temperatures primarily depends on the ability of plant membranes to prevent injury and maintain integrity (Zhang et al., 2012). Instability of the lipid membrane is directly related to lipid composition. The increase in the proportion of 
unsaturated fatty acids allows for the maintenance of membrane fluidity, which helps maintain its functions during exposure to low temperatures (Upchurch, 2008).

In higher plants, reactive oxygen species (ROS) are generated during normal aerobic metabolism, such as during photosynthesis and respiration. However, under stress conditions, such as low temperatures, ROS are produced at high levels, which may result in damage to DNA, proteins, and lipids. Under biotic and abiotic stress conditions, antioxidant enzymes play an important role in removing ROS.

Li et al. (2013) evaluated antioxidant enzyme expression and ROS content in wheat seeds 3 days after sowing under low temperature conditions. They observed a progressive increase in ROS content and, consequently, increased expression of antioxidant enzymes. Expression was evaluated up to the 7th day after sowing. However, in this study, the period of seed exposure to low soaking temperature may not have been sufficient for increasing antioxidant enzyme expression, which may be explained by the effect of low temperatures on reducing the germination metabolism, indicating lower respiratory activity and thus lower ROS production.

Low soaking temperatures may be related to lower synthesis of enzymes necessary for degradation of starch for growth of the embryo, explaining the delay in the germination process. In maize, $\alpha$-amylase, upon promoting starch hydrolysis, produces the carbohydrates necessary for embryo development, enabling germination to proceed (Franco et al., 2002). However, Oliveira et al. (2013) found that in addition to amylase genes, various other genes may be involved in controlling this trait, including the physiological quality of seeds, for example, and the genes directly related to respiration.

In general, based on the expression profile of the $\alpha$-amylase enzyme, there was no differential expression in lines at the same temperature.

$\alpha$-Amylase activity is the highest after root protrusion because it increases the reserves available for promoting seedling growth; thus, expression of this enzyme in seeds soaked at $10^{\circ} \mathrm{C}$ was nearly non-existent; the low temperature delayed the period of protrusion.

Variation in the expression of heat-resistant proteins was observed in seeds of the lines evaluated. Andrade et al. (2013) reported that heat-resistant proteins were differentially expressed in seeds with different genotypes.

The mechanisms involved in cold tolerance have also been examined by determining the expression of transcripts in a range of species, including Arabidopsis thaliana (Chen et al., 2002) and wheat (Winfield et al., 2010). In general, large variation in gene expression was observed in dry seeds and seeds soaked at $10^{\circ}$ and $25^{\circ} \mathrm{C}$ for $48 \mathrm{~h}$ from different lines.

The $A O X 1$ gene was expressed in dry seeds of the lines tolerant to cold, indicating its potential as a good marker for the selection of genotypes that are tolerant to low germination temperatures as it allows for accelerated analyses because the seeds do not have to be soaked.

The $A O X$ gene has been suggested to be an important functional marker for selection of plants that are resistant to abiotic stresses. This is because when the plants are subjected to adverse abiotic conditions, a specific gene of alternative oxidase is highly induced, while codification of more than 60 genes expressed in the phosphorylation chain and in the classic tricarboxylic acid cycle were generally unaltered.

Karpova et al. (2002) analyzed the expression of $3 A O X$ genes in 2 types of maize with mitochondrial mutation and observed that in mutants, respiration was affected and growth was altered. Based on analysis of the mutants, these authors suggested that damage to the mitochondria of maize not only indicate to the nucleus that mitochondrial function is compro- 
mised, but also confer information regarding the location of the lesion, resulting in a differential induction of $A O X$ genes. Thus, the induction pattern of these genes in maize may serve as a selective marker for diverse mitochondrial defects.

Mhadhbia et al. (2013) analyzed AOX1 gene expression levels in genotypes of Medicago truncatula with different levels of tolerance to salt stress. The results of this study revealed specific induction of AOX1 in the roots of tolerant genotypes; genotypes showing higher AOX1 expression had fewer biochemical alterations, such as lipid peroxidation and production of ROS.

The gene ZmMPK-17 codifies for a type of protein kinase activated by mitogens. These proteins convert extracellular stimuli into intracellular responses while concurrently amplifying the transmission signal. This action ensures adequate performance and possibly the survival of a determined organism during times of stress. These proteins act in signaling defense, ensuring the survival of the species. The time of exposure of the seeds to low temperature may have been insufficient for activating this mechanism and, thus, separation of the materials into levels of vigor was not possible.

After soaking the seeds at $10^{\circ} \mathrm{C}$ for $48 \mathrm{~h}$, the $Z m A N-13$ gene was effective for distinguishing lines that were tolerant to low germination temperatures from non-tolerant lines. The $Z m A N-13$ gene may also be a potential marker for selecting cold-tolerant materials during germination. Xuan et al. (2011) studied $Z m A N-13$ gene expression in maize seedlings and observed that the expression of this gene increased as the time of exposure of seedlings to low temperature increased. These same authors studied the expression of this gene in the leaves, root, stem, pistil, stamen, style, bract, and coleoptile, and observed that expression was greater in the leaves. In this study, the gene $Z m A N-13$ was found to be useful for studying the responses of the seeds to low germination temperatures.

The changes observed in the physiological analyses, transcriptomics, proteomics, and fatty acid content analysis when the seeds from 6 maize lines were subjected to low germination temperature reinforced the complexity of the characteristic of cold tolerance. It is necessary to use genes that make it possible to separate lines with high and low tolerance to low germination temperatures, such as $A O X 1$ and $Z m A N-13$. These genes, associated with the traits evaluated in this study, may assist in obtaining maize lines tolerant to cold.

\section{CONCLUSIONS}

Lines 44, 54, and 57 were more susceptible to low germination temperatures, while lines 63, 64, and 91 were more tolerant to low-temperature stress conditions.

The fatty acid profile was altered in the lines as temperature and soaking time were varied. Seeds from lines that were most susceptible to low germination temperatures showed higher saturated fatty acid content.

Expression of $\alpha$-amylase enzyme in seeds soaked for $72 \mathrm{~h}$ at $10^{\circ} \mathrm{C}$ was lower than in seeds soaked for $72 \mathrm{~h}$ at $25^{\circ} \mathrm{C}$.

$\alpha$-Amylase expression in the lines within the same soaking temperatures did not show differential expression.

The genes $A O X 1$ and $Z m A N-13$ are useful for selecting maize lines resistant to low germination temperatures. 


\section{REFERENCES}

Alfenas AC (2006a). Eletroforese de isoenzimas e proteínas afins: fundamentos e aplicações em plantas e microorganismos. Universidade Federal de Viçosa, Viçosa.

Alfenas AC (2006b). Eletroforese e marcadores bioquímicos em plantas e microrganismos. Universidade Federal de Viçosa, Viçosa.

Andrade T, Von Pinho EV, Von Pinho RG, Oliveira GE, et al. (2013). Physiological quality and gene expression related to heat-resistant proteins at different stages of development of maize seeds. Genet. Mol. Res. 12: 3630-3642.

Baek KH and Skinner DZ (2003). Alteration of antioxidant enzyme gene expression during cold acclimation of nearisogenic wheat lines. Plant Sci. 165: 1221-1227.

Blackman RK, Sanicola M, Raftery LA, Gillevet T, et al. (1991). An extensive 3' cis-regulatory region directs the imaginal disk expression of decapentaplegic, a member of the TGF- family in Drosophila. Development 111: 657-666.

BRASIL (2009). Regras para análise de sementes. Ministério da Agricultura, Pecuária e Abastecimento, Brasília.

Chen W, Provart NJ, Glazebrook J, Katagiri F, et al. (2002). Expression profile matrix of Arabidopsis transcription factor genes suggests their putative functions in response to environmental stresses. Plant Cell 14: 559-574.

Chinnusamy V, Zhu J and Zhu JK (2007). Cold stress regulation of gene expression in plants. Trends Plant Sci. 12: 444-451.

Farooq M, Aziz T, Cheema ZA, Hussain M, et al. (2008). Activation of antioxidant system by $\mathrm{KCl}$ improves the chilling tolerance in hybrid maize. J. Agron. Crop Sci. 194: 438-448.

Ferreira DF (2004). Sistema de análise de variância (SISVAR). Universidade Federal de Lavras, Lavras.

Franco OL, Rigden DJ, Melo FR and Grossi de-Sá MF (2002). Plant alpha-amylase inhibitors and their interaction with insect alpha-amylases. Eur. J. Biochem. 269: 397-412.

Hughes MA and Dunn MA (1996). The molecular biology of plant acclimation to low temperature. J. Experim. Bot. 47 : 291-305.

Karpova OV, Evgeny V, Kuzmin A, Thomas E, et al. (2002). Differential expression of alternative oxidase genes in maize mitochondrial mutants. Plant Cell 14: 3271-3284.

Li X, Haidong J, Fulai L, Jian C, et al. (2013). Induction of chilling tolerance in wheat during germination by pre-soaking seed with nitric oxide and gibberellin. Plant Growth Regul. 71: 31-40.

Maguire JD (1962). Speed of germination aid in selection and evaluation for seedling emergence and vigor. Crop Sci. 2: 176-177.

Mhadhbia H, Fotopoulos V, Mylona PV, Jebara M, et al. (2013). Alternative oxidase 1 (Aox1) gene expression in roots of Medicago truncatula is a genotype-specific component of salt stress tolerance. J. Plant Physiol. 170: 111-114.

Oliveira GE, Von Pinho RG, Andrade T, Vilela E, et al. (2013). Physiological quality and amylase enzyme expression in maize seeds. Cienc. Agrotec. 37: 40-48.

Rasmussen IA (2000). Barley seed vigour and mechanical weed control. Weed Res. 40: 219-230.

Şahin-Çevik M (2013). Identification and expression analysis of early cold-induced genes from cold-hardy Citrus relative Poncirus trifoliata (L.) Raf. Gene 512: 536-545.

Shahandashti SSK, Maali AR, Zeinali H and Ramezanpour SS (2013). Change in membrane fatty acid compositions and cold-induced responses in chickpea. Mol. Biol. Rep. 40: 893-903.

Tyagi S, Bratu DP and Kramer FR (1998). Multicolor molecular beacons for allele discrimination. Nat. Biotechnol. 16: 49-53.

Uemura M, Joseph RA and Steponkus PL (1995). Cold acclimation of Arabidopsis thaliana (effect on plasma membrane lipid composition and freeze-induced lesions). Plant Physiol. 109: 15-30.

Ullmannová K, Středa T and Chloupek O (2013). Use of barley seed vigour to discriminate drought and cold tolerance in crop years with high seed vigour and low trait variation. Plant Breed. 132: 295-298.

Upchurch RG (2008). Fatty acid unsaturation, mobilization, and regulation in the response of plants to stress. Biotechnol. Lett. 30: 967-977.

Winfield MO, Lu C, Wilson ID, Coghill JA, et al. (2010). Plant responses to cold: transcriptome analysis of wheat. Plant Biotechnol. J. 8: 749-771.

Xuan N, Jin Y, Zhang H, Xie Y, et al. (2011). A putative maize zinc-finger protein gene, ZmAN13, participates in abiotic stress response. Plant Cell Tiss. Org. 107: 101-112.

Yang G, Zou H, Wu Y, Liu H, et al. (2011). Identification and characterisation of candidate genes involved in chilling responses in maize (Zea mays L.). Plant Cell Tiss. Org. 106: 127-141.

Zhang J, Liu H, Sun J, Li B, et al. (2012). Arabidopsis fatty acid desaturase FAD2 is required for salt tolerance during seed germination and early seedling growth. PloS One 7: 1-12.

Zhou J, Wang J, Shi K, Xia XJ, et al. (2012). Hydrogen peroxide is involved in the cold acclimation-induced chilling tolerance of tomato plants. Plant Physiol. Biochem. 60: 141-149. 